удК 657.1.011.56

\title{
АДМІНІСТРУВАННЯ ОБЛІКОВО-АНАЛІТИЧНИХ ДАНИХ ІНФОРМАЦІЙНОЇ СИСТЕМИ ХЛІБОЗАВОДУ
}

\author{
ADMINISTRATION OF ACCOUNTING \\ AND ANALYTICAL DATA OF THE INFORMATION \\ SYSTEM OF THE BAKERY PLANT
}

\author{
Волошин Володимир Степанович \\ кандидат економічних наук, доцент, \\ Національний університет водного господарства та природокористування \\ ORCID: https://orcid.org/0000-0001-8108-0126 \\ Гаврилюк Максим Сергійович \\ студент, \\ Національний університет водного господарства та природокористування \\ ORCID: https://orcid.org/0000-0003-1149-6251 \\ Voloshyn Volodymyr, Havryliuk Maksym \\ National University of Water and Environmental Engineering
}

\begin{abstract}
Досліджено наукові точки зору, що стосуються питання адміністрування обліково-аналітичних даних інфрормаційної системи хлібозаводу. Наведено засоби вдосконалення рівня використання цифрових технологій у харчовій промисловості. Розглянуто функціональні можливості програмного комплексу «Дебет Плюс» 3 конфрігурацією «Хлібозавод, пекарня». Описано прикладне програмне забезпечення «1С: Бухгалтерія хлібобулочного і кондитерського підприємства». Виділено підсистеми бізнес-процесів даної конфігурації. Розроблено довідник «Магазини», а також документ «Поставка товарів», що систематизуються у журналі «Поставка в магазин» у підсистемі «1С. Маркетинг та Продажі». Створено звіт «Реалізація товарів» 3 можливістю групування по контрагентах та магазинах, а також наочне зображення даних. Автоматизовано процес введення інформації для мінімізації помилок користувачів, за рахунок створення форм елементів та списку сутностей.

Ключові слова: облік, інформаційні системи, хлібозавод, аналіз, аналітичні дані, автоматизація процесів.
\end{abstract}

Исследовано научные точки зрения, которые касаются вопроса администрирования учетно-аналитических данных инорормационной системы хлебозавода. Приведены средства совершенствования уровня использования цифрровых технологий в пищевой промышленности. Рассмотрены функциональные возможности программного комплекса «Дебет Плюс» с конфигурацией «Хлебозавод, пекарня». Описано прикладное программное обеспечение «1С: Бухгалтерия хлебобулочного и кондитерского предприятия». Выделено подсистемы бизнес-процессов данной консригурации. Разработан справочник «Магазины», а также документ «Поставка товаров» в подсистеме «1С. Маркетинг и Продажи». Создан отчет «Реализация товаров» с возможностью группировки по контрагентам и магазинам, а также наглядное изображение данных. Автоматизирован процесс ввода информации для минимизации ошибок пользователей, за счет создания форм элементов и списка сущностей.

Ключевые слова: учет, иноормационные системы, хлебозавод, анализ, аналитические данные, автоматизация процессов.

The article examines the scientific topical issues on the maintenance of accounting and analytical data of the information system of the bakery plant. The means of improving the level of use of digital technologies in the food industry are given. Considered the functional capabilities of the software package «Debit Plus» - Ukrainian cross-platform automated enterprise management system with the configuration «Bakery plant, bakery». This system has modules: work with applications for finished products, release of finished products in the expedition, accounting for raw materials, write-off of raw materials into production, accounting of work and salary. Described the application software «Accounting of the bakery and confectionery enterprise» which is developed by $1 \mathrm{C}$ - the company specializing in distribution, support and development of computer programs and databases of business and house function. Allocated subsystem business processes this configuration: normative-reference information, operative accounting of production, order management, dispatching of orders, realization and delivery. Described configurations «Bakery 
plant Debit Plus» and «1C: Accounting of the bakery plant and confectionery company» contain a large number of functional modules. For large and medium-sized enterprises, this can lead to information redundancy. The result of such actions is inefficient and timely management decisions. To systematize the configuration data, a logical data model is created, consisting of the following entities: production, individuals, supply, waste, customer orders, production orders, resource reserves, stores. This model is designed for administration and accounting of the bakery plant information system. The directory «Shops» was developed, as well as the document «Supply of goods», which is systematized in the magazine «Supply to the store» in the subsystem «1C Marketing and Sales». Are highlighted the main details of the information system: address, counterparty, division, store, delivery date, contract, nomenclature, quantity, units of measurement, price. The process of entering information to minimize user errors is automated by creating element forms and a list of entities. Are highlighted the types of attribute data in the information system for the administration of accounting and analytical information. These can be basic, such as text, date, integer, and fractional numbers, or contain links to other configuration objects: directories, documents.

Keywords: accounting, information systems, bakery plant, analysis, analytical data, process automation.

Постановка проблеми. В умовах бурхливого розвитку інформаційних технологій в сучасному суспільстві, досить гостро постає проблема підтримки в актуальному стані обліково-аналітичних даних інфрормаційної системи типового хлібозаводу. На сьогоднішній день питання розвитку інформаційних систем (IC) загалом та бухгалтерських зокрема $€$ досить актуальним. Незалежно від розмірів підприємства та його фрорми власності, застосовування БІС (бухгалтерських інфрормаційних систем) $€$ вимогою часу. Також у діяльності будь-якого підприємства завжди велику роль відіграє правильно налагоджений облік. Враховуються товари, гроші, договори, постачальники і покупці, співробітники і багато іншого. Вся ця інфрормація важлива при роботі підприємства для правильної оцінки і планування подальшої діяльності. Маркетинговий відділ із залученням досвідченої групи аналітиків на таких підприємствах, повинен орієнтуватися на дослідження ринку реалізації продукції, що у свою чергу допоможе знайти цілісні рішення. Також потрібно створювати обліковоаналітичні звіти, що проводять глибокий аналіз інформації та стимулюють використання наявних економічних можливостей та механізмів на ринку. Адміністрування обліково-аналітичних даних інорормаційної системи хлібозаводу проводиться 3 метою надання допомоги керівникам структурних підрозділів у системі підтримки прийняття рішень.

Аналіз останніх досліджень і публікацій. Питанням удосконалення процесів виробництва хлібопекарської промисловості часто зустрічається у роботах вітчизняних та закордонних дослідників. Так, наприклад, В. В. Струнін та Т. М. Філоненко аналізували сучасний стан та перспективи розвитку ринку хлібобулочних виробів та встановили спад виробництва в Україні в першу чергу за рахунок зміни структури споживання, високій мірі зносу устаткування [1]. Шендригоренко М. Т. та Лядська В. В. досліджували проблеми та перспективи розвитку обліку в умовах цисрової економіки та вважали, що консерватизм в бухгалтерському обліку не повинен втручатися в інновації [2]. Макаренко В. В. здійснив обґрунтування, що у сумарному обсязі продукції всієї харчової промисловості України хлібопекарська галузь займає одне із провідних місць, а хлібобулочні вироби є важливим продуктом харчування для більшості населення України, а для найбідніших верств основним [3]. Серед закордонних вчених, які досліджували технології виготовлення хліба, можна відмітити: C. M. Rosell, S. Cauvain, M. Seguchi, C. Wrigley, I. Batey [4] та інші.

Мета дослідження. Виявити проблемні області та розробити власні засоби адміністрування обліково-аналітичних даних інформаційної системи хлібозаводу.

Виклад основного матеріалу. Харчова промисловість України є однією зі стратегічних галузей розвитку вітчизняної економіки, провідне місце у якій займає хліб. Досліджуючи IC, що призначені для автоматизації обліку хлібопекарської промисловості, встановлено, що найбільшим конкурентом $1 \mathrm{C} \epsilon$ програмний комплекс «Дебет Плюс» 3 конорігурацією «Хлібозавод, пекарня» [5]. Дана система має модульну структуру та дає можливість налаштувати фрункціональність, необхідну потребам підприємства.

Конфрігурація «Хлібозавод, пекарня» має такі фрункціональні можливості:

1. Робота із заявками на готову продукцію. У системі $\epsilon$ документ «Заявка», за допомогою якого збирається інфрормація від покупців про необхідну кількість готової продукції. Заявки ведуться в розрізі конкретних точок доставки (магазинів). На підставі заявок від покупців фрормується заявка у виробництво.

2. Відпуск готової продукції в експедиції. По складу готової продукції ведеться позмінний облік, а накладні на відвантаження покупцям 
фрормуються автоматично на підставі прийнятих заявок. Відпускні ціни на готову продукцію для покупців автоматично беруться 3 прайслистів. Також $€$ можливість використовувати різні прайс-листи для різних точок доставки одного і того ж покупця. В даному модулі передбачено надання послуг на відпустку давальницької продукції кінцевим споживачам.

3. Облік сировини. Борошно оприбутковується на склад і виписується у виробництво 3 якісними показниками (зокрема, зі значенням вологості). Запаси сировини у виробництві передаються з зміни в зміну на підставі актів передачі залишків.

4. Списання сировини у виробництво. При списанні сировини по рецептурі система автоматично контролює залишки і списує тільки те, що $€$ в наявності. При відсутності будь-якого сировини пропонує користувачеві вручну вибрати з таблиці замін альтернативну сировину. У кінці зміни фрормується звіт по роботі зміни, в якому зазначаються залишки сировини на початок зміни, кількість списаного сировини на кожний конкретний вид продукції, кількостей прийнятого зі складу та переданого на склад сировини і залишки на кінець.

5. Облік праці та заробітної плати. У кінці кожної зміни начальник зміни заводить «Робочий аркуш». У даний звіт автоматично заноситься виготовлена за зміну продукція. В кінці місяця кожен майстер формує «Табель обліку робочого часу», в який для робітників обраної бригади система автоматично з робочих аркушів вибирає відпрацьований час, кількість вечірніх, нічних годин в розрізі видів робіт (розцінок) [5].

Альтернативою конорігурації «Хлібозавод, пекарня. Дебет Плюс» для адміністрування обліково-аналітичних даних інсрормаційної системи хлібозаводу є програмний продукт «1C: Бухгалтерія хлібобулочного і кондитерського підприємства» [6] призначений для автоматизації обліку діяльності малих і середніх організацій, що займаються виробництвом, продажем хлібобулочних і кондитерських виробів. Функціональні можливості даної системи зображено на рис. 1.

Відповідно до даного рисунку, розглянемо більш детальніше основні підсистеми бізнеспроцесів даної конорігурації. Нормативнодовідкова інфрормація: підсистема містить набір довідників і регістрів відомостей для забезпечення роботи фрункціоналу хлібобулочного і кондитерського виробництва. Управління замовленнями: призначена для автоматизації роботи користувачів по введенню нових замовлень клієнтів (магазинів), коригування замовлень, створення замовлень з зовнішніх систем, автоматичного створення замовлень за даними рознарядки, автоматизації механізму повернення черствої продукції.

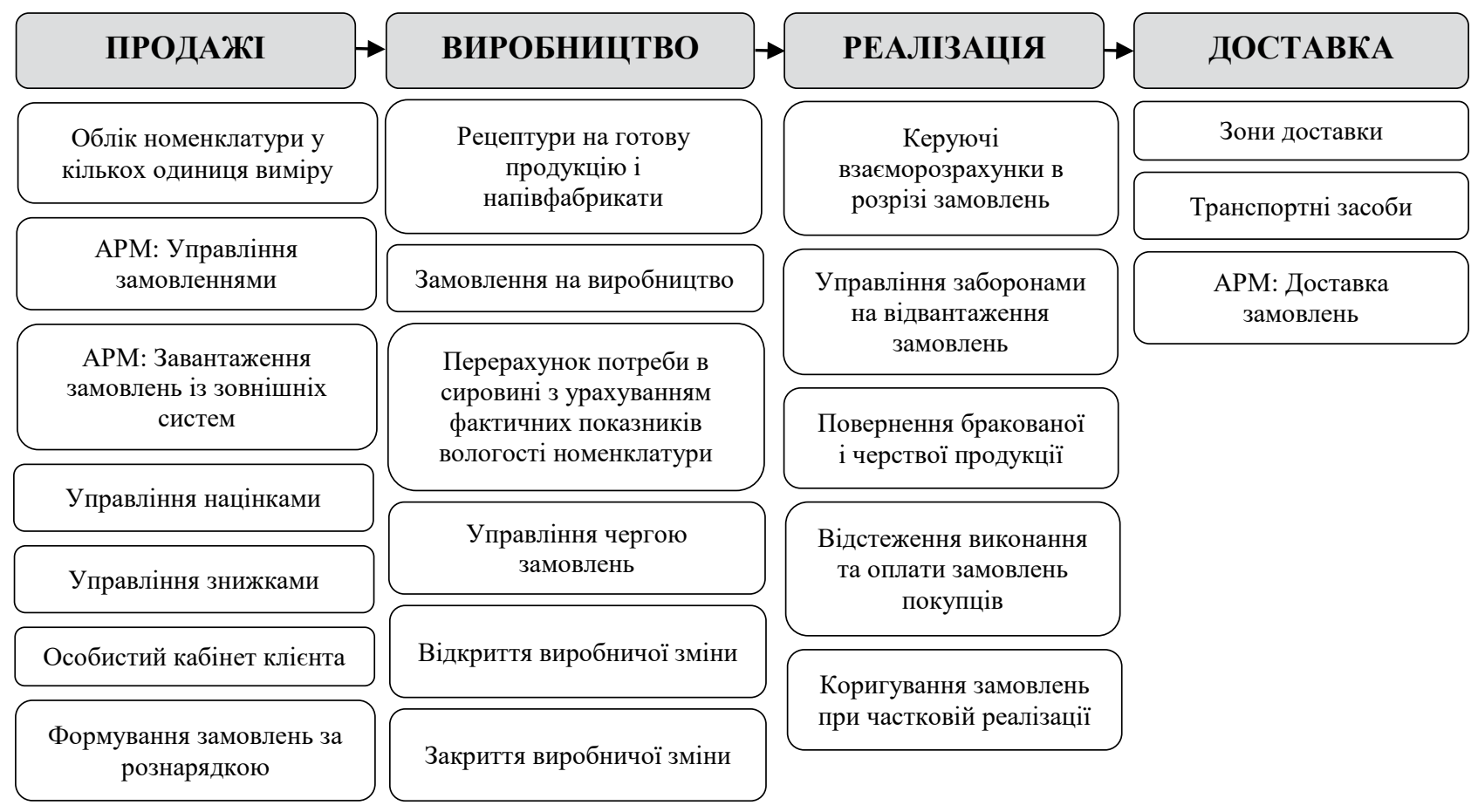

Рис. 1. Бізнес процеси конфрігурації «Бухгалтерія хлібобулочного і кондитерського підприємства» Джерело: розроблено автором на основі [6] 
Таблиця 1

Реквізити сутностей та атрибутів у системі 1С для адміністрування обліково-аналітичних даних інформаційної системи хлібозаводу

\begin{tabular}{|c|c|c|}
\hline Ім'я реквізиту & Тип даних в 1C & Довжина \\
\hline \multicolumn{3}{|c|}{ Довідник «Магазини» } \\
\hline Адреса & Строка & 150 \\
\hline Контрагент & Справочник. Ссылка. Контрагенты & - \\
\hline \multicolumn{3}{|c|}{ Документ «Поставка товарів» } \\
\hline Підрозділ & Справочник. Ссылка. Структурные единицы & - \\
\hline Контрагент & Справочник. Ссылка. Контрагенты & - \\
\hline Магазин & Справочник. Ссылка. Магазини & - \\
\hline Дата поставки & Дата & - \\
\hline Договір & Справочник. Ссылка. Договоры контрагентов & - \\
\hline Номенклатура & Справочник. Ссылка. Номенклатура & - \\
\hline Кількість & Число & 12 \\
\hline Одиниці виміру & Справочник. Ссылка. Единицы измерения & - \\
\hline Ціна & Число & 12 \\
\hline Сума & Число & 12 \\
\hline ПДВ & Число & 12 \\
\hline
\end{tabular}

Джерело: розроблено автором

Оперативний облік виробництва: у даній підсистемі реалізовані фрункціональні можливості використання ресурсної специфрікації для виробленої номенклатури, фрормування замовлень на виробництво, розрахунок сировини і матеріалів за поточної вологості борошна і по необхідному для виробництва кількості. Диспетчеризація замовлень на виробництво: розроблений механізм диспетчеризації замовлень на виробництво. Реалізація та доставка: у підсистемі реалізовані механізми введення документа «Реалізація товарів» на підставі документа «Замовлення покупця», розроблено документ «Замовлення на доставку» та робоче місце 3 управління доставкою.

Описані конорігурації «Хлібозавод, пекарня. Дебет Плюс» та «1С: Бухгалтерія хлібобулочного і кондитерського підприємства» містять у собі досить велику кількість функціональних модулів, що для малих та середніх підприємств може призвести до надлишковості інформації і як результат - не ефеективних та своєчасних управлінських рішень. Для систематизації даних конфрігурації спроєктуємо логічну модель даних для адміністрування та обліку інсрормаційної системи хлібозаводу (рис. 2).

Відповідно до рис. 2 у підсистемі «1C. Маркетинг та Продажі» було розроблено довідник «Магазини», а також документ «Поставка товарів», що систематизуються у журналі «Поставка в магазин». Для отримання вихідної інформації створено звіт «Реалізація товарів» 3 можливістю групування по контрагентах та магазинах. У таблиці 1 наведена інсрормація про реквізити створених сутностей та атрибутів у системі $1 \mathrm{C}$.

Типи даних атрибутів у системі 1С для адміністрування обліково-аналітичної інфрормації, можуть бути базовими, або містити посилання на інші об'єкти конфрігурації. Також максимально автоматизовано процес введення інфрормації для мінімізації помилок користувачів, за рахунок створення фрорм елементів та списку сутностей.

Висновки. Сьогодні на IT ринку пропонується досить велика кількість програмного забезпечення для адміністрування обліковоаналітичних даних інфрормаційної системи хлібозаводу, серед якого можна виділити конфрігурацію «Хлібозавод, пекарня. Дебет Плюс» та «1С: Бухгалтерія хлібобулочного і кондитерського підприємства». Основні фрункціональні можливості першої - робота із заявками на готову продукцію, відпуск готової продукції в експедиції, облік та списання сировини у виробництво, - а другої: управління замовленнями, диспетчеризація замовлень на виробництво, облік реалізації та доставки. Для систематизації даних конфрігурації було розроблено логічну модель даних адміністрування та обліку інфрормаційної системи хлібозаводу, а також створено довідник «Магазини» та документ «Поставка товарів», що виступають складовими бізнес-процесів реалізації продукції. 


\begin{tabular}{|c|c|c|}
\hline Документ & Довідник & Документ \\
\hline Виробництво & Фізичні особи & Співробітники \\
\hline Номер & Код фрізичної особи & Код співробітника \\
\hline Дата & ПІБ & Фізична особа \\
\hline Підрозділ & Дата народження & ПІБ \\
\hline $\begin{array}{l}\text { Замовлення на } \\
\text { виробництво }\end{array}$ & Стать & Рахунок рохрахунків 3 \\
\hline Номенклатура & довідник & Рахунок рохрахунків 3 \\
\hline Кількість & Наряди & підзвітними \\
\hline Од. виміру & Номер & Рахунок рохрахунків за \\
\hline Відповідальний & Дата & \\
\hline & Підрозділ & Документ \\
\hline Таблична частина & & Замовлення \\
\hline Запаси & & 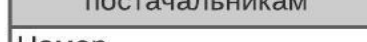 \\
\hline Номенклатура & Таблична частина & Номер \\
\hline Кількість & Бригади & Дата \\
\hline Од. виміру & Номер & Контрагент \\
\hline & Співробітник & Договір \\
\hline Відходи & & Дата поставки \\
\hline Номенклатура & Операції & Доставлено \\
\hline Кількість & Номер & Таблична частина \\
\hline Од. виміру & Дата & Товари \\
\hline & Замовлення покупця & Номенклатура \\
\hline Документ & Номенклатура & Кількість \\
\hline Замовлення покупця & Од. виміру & Од. виміру \\
\hline Номер & Кількість & Rовівиия \\
\hline Дата & Вартість & Довідник \\
\hline Контрагент & & Магазини \\
\hline Договір & Довідник & Код \\
\hline Виконано & Контрагент & Назва \\
\hline & Код & Контрагент \\
\hline Таблична частина & Назва & \\
\hline Товари & & Документ \\
\hline Номенклатура & Довідник & Поставка товарів \\
\hline Кількість & Номенклатура & Код \\
\hline Од. виміру & Код & Підрозділ \\
\hline & Назва & Контрагент \\
\hline Документ & & Магазин \\
\hline Замовлення на & Таблична частина & Дата поставки \\
\hline виробництво & Запаси & Договір \\
\hline Номер & Номенклатура & \\
\hline Дата & Характеристика & Таблична частина \\
\hline Підрозділ & Кількість & Товари \\
\hline Стан & Од. виміру & Номенклатура \\
\hline Дата початку & & Кількість \\
\hline Дата закінчення & Ресурси & Од. виміру \\
\hline Номенклатура & Pecypc & Ціна \\
\hline Кількість & Тривалість & Сума \\
\hline Од. виміру & Дата початку & $\%$ пдв \\
\hline Замовлення покупця & Дата закінчення & Сума пдв \\
\hline
\end{tabular}

Рис. 2. Логічна модель адміністрування обліково-аналітичних даних інформаційної системи хлібозаводу 


\section{СПИСОК ВИКОРИСТАНИХ ДЖЕРЕЛ:}

1. Струнін В. В., Філоненко Т. М. Вітчизняний ринок хлібобулочних виробів: сучасний стан та перспективи розвитку. Ефрективна економіка. 2014. № 12. URL: http://www.economy.nayka.com.ua/?op=1\&z=3661 (дата звернення: 27.04.2021).

2. Шендригоренко М. Т., Лядська В. В. Проблеми та перспективи розвитку обліку в умовах цифрової економіки. Економіка та суспільство. 2020. Випуск 22. URL: https://economyandsociety.in.ua/index.php/journal/ article/view/89/84 (дата звернення: 27.04.2021).

3. Макаренко В. В. Вся правда про хліб. Агро Перспектива. 2007. № 6. С. 24-27.

4. Breadmaking. ScienceDirect : Journals \& Books : веб-сайт. URL: https://www.sciencedirect.com/topics/foodscience/breadmaking (дата звернення: 27.04.2021).

5. Автоматизація обліку хлібозаводу, хлібокомбінату, пекарні. Конорігурація «Хлібозавод, пекарня». Дебет Плюс : веб-сайт. URL: https://debet.com.ua/uk/industries/bread (дата звернення: 21.03.2021).

6. 1C: Бухгалтерія хлібобулочного і кондитерського підприємства. Компанія «Онлайн» : веб-сайт. URL: https://www.online-ufa.ru/market/programmy-1s-predpriyatie/1c-bukhgalteriya-khlebobulochnogo-i-konditerskogopredpriyatiya/ (дата звернення: 21.03.2021).

\section{REFERENCES:}

1. Strunin, V.V., \& Filonenko, T.M. (2014). Vitchyznianyi rynok khlibobulochnykh vyrobiv: suchasnyi stan ta perspektyvy rozvytku [The domestic market of bakery products: current status and development prospects]. Efektyvna ekonomika - Efficient economy, 12. Retrieved from: http://www.economy.nayka.com.ua/?op=1\&z=3661 (in Ukrainian)

2. Shendryhorenko, M.T., \& Liadska V.V. (2020). Problemy ta perspektyvy rozvytku obliku v umovakh tsyfrovoi ekonomiky [Problems and prospects of accounting development in the digital economy]. Ekonomika ta suspilstvo Economy and society, 22. https://doi.org/10.32782/2524-0072/2020-22-47 (in Ukrainian)

3. Makarenko, V.V. (2007). Vsia pravda pro khlib [All true is about bread]. Ahro Perspektyva-Agro Perspective, 6, 24-27. (in Ukrainian)

4. Breadmaking. ScienceDirect: Journals \& Books. Retrieved from: https://www.sciencedirect.com/topics/ food-science/breadmaking

5. 1S: Bukhhalteriia khlibobulochnoho i kondyterskoho pidpryiemstva [1C: Accounting of the bakery and confectionery enterprise]. Retrieved from: https://www.online-ufa.ru/market/programmy-1s-predpriyatie/1c-bukhgalteriya-khlebobulochnogo-i-konditerskogo-predpriyatiya 